Document downloaded from:

http://hdl.handle.net/10251/84198

This paper must be cited as:

Solis Díaz, C.; Navarrete Algaba, L.; Serra Alfaro, JM. (2013). Study of Pr and Pr and Co doped La2NiO4+\&\#948; as cathodes for La5.5WO11.25-\&\#948; based protonic conducting fuel cells. Journal of Power Sources. 240:691-697. doi:10.1016/j.jpowsour.2013.05.055

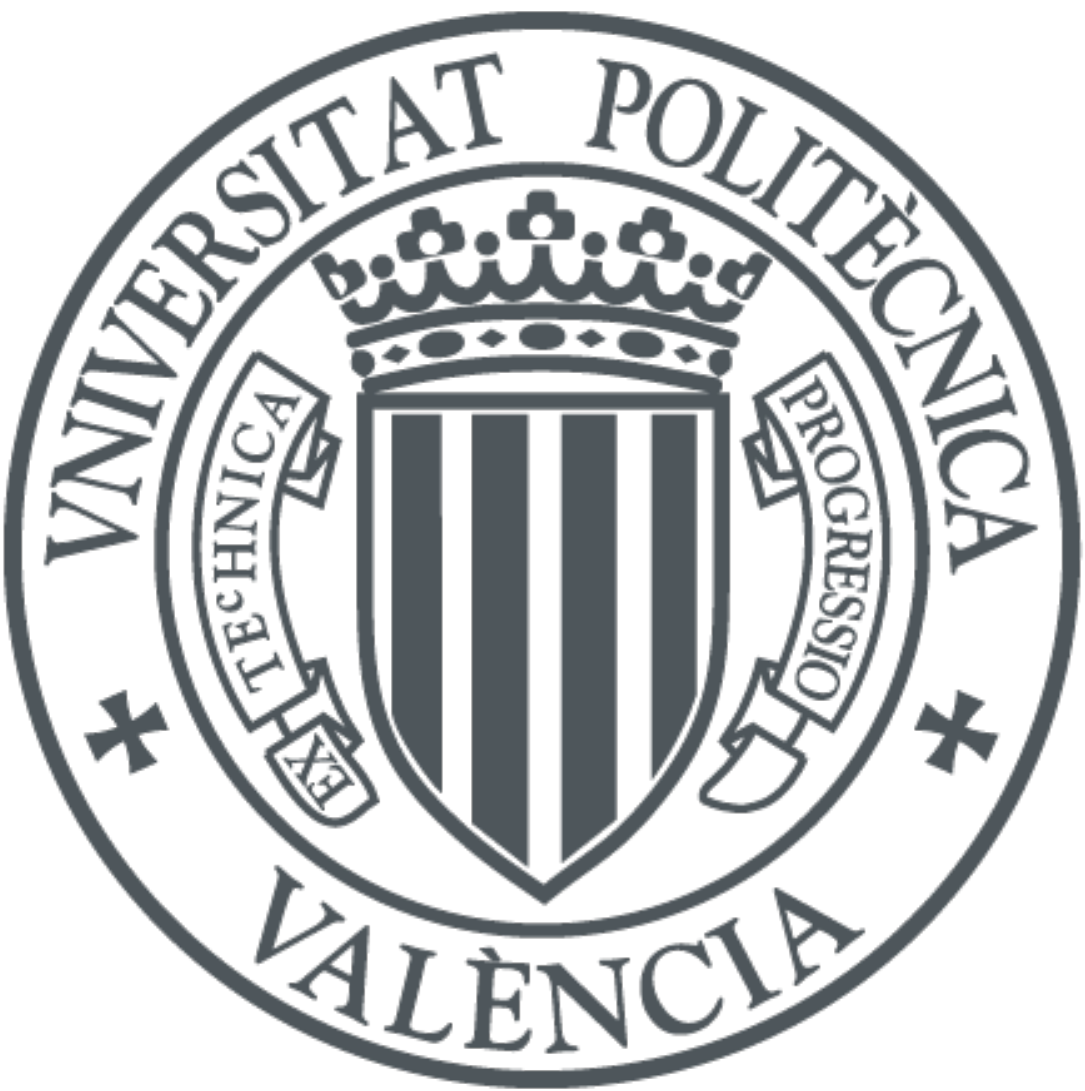

The final publication is available at

http://doi.org/10.1016/j.jpowsour.2013.05.055

Copyright Elsevier

Additional Information 


\title{
Study of $\mathrm{Pr}$ and $\mathrm{Pr}$ and Co doped $\mathrm{La}_{2} \mathrm{NiO}_{4+\delta}$ as cathodes
}

\section{for $\mathrm{La}_{5.5} \mathrm{WO}_{11.25-\delta}$ based protonic conducting fuel cells}

\author{
Cecilia Solís, Laura Navarrete and José M. Serra*
}

Instituto de Tecnología Química (Universidad Politécnica de Valencia - Consejo Superior de Investigaciones Científicas), Av. Naranjos s/n, E-46022 Valencia (SPAIN)

\section{Journal of Power Sources 240 (2013) 691-697 (doi: 10.1016/j.jpowsour.2013.05.055)}

The mixed ionic-electronic conductor $\mathrm{La}_{2} \mathrm{NiO}_{4+\delta}$ was investigated as potential cathode material for protonic conducting solid oxide fuel cells (PC-SOFCs) based on $\mathrm{La}_{5.5} \mathrm{WO}_{11.25-\delta}$ electrolyte. Firstly the chemical compatibility between cathode and electrolyte phases $\left(\mathrm{La}_{2} \mathrm{NiO}_{4+\delta}\right.$ and $\mathrm{La}_{5.5} \mathrm{WO}_{11.25-\delta}$ respectively) was studied. Then, the electrochemical properties of this cathode were improved by partially substituting La and/or $\mathrm{Ni}$, specifically $\mathrm{La}_{1.5} \operatorname{Pr}_{0.5} \mathrm{NiO}_{4+\delta}$ and $\mathrm{La}_{1.5} \mathrm{Pr}_{0.5} \mathrm{Ni}_{0.8} \mathrm{Co}_{0.2} \mathrm{O}_{4+\delta}$ were considered. These two doped materials showed improved electrical conductivity and reduced polarization resistance, when tested as cathode in symmetrical cells. In a second step, the microstructure of $\mathrm{La}_{1.5} \mathrm{Pr}_{0.5} \mathrm{Ni}_{0.8} \mathrm{Co}_{0.2} \mathrm{O}_{4+\delta}$ was optimized by varying the firing temperature of the cathode. The performance of these mixed conductors is limited by medium frequencies associated processes while they show lower polarization resistances (Rp) than conventional composites based on $\mathrm{La}_{5.5} \mathrm{WO}_{11.25-\delta}$ and pure electronic conductors. $\mathrm{La}_{1.5} \mathrm{Pr}_{0.5} \mathrm{Ni}_{0.8} \mathrm{Co}_{0.2} \mathrm{O}_{4+\delta}$ cathode sintered at $1050{ }^{\circ} \mathrm{C}$ exhibits the best electrochemical performance on a $\mathrm{La}_{5.5} \mathrm{WO}_{11.25-\delta}$-based PC-SOFC, achieving $\mathrm{Rp}=0.62 \Omega \cdot \mathrm{cm}^{2}$ at $750{ }^{\circ} \mathrm{C}$ in wet air.

Keywords: PC-SOFC, Cathodes, Proton Conductor, Lanthanum nickelate, Electrochemical Impedance Spectroscopy, Lanthanum tungstate

[*] Corresponding author, jmserra@itq.upv.es; Tel: +34.963.879.448; Fax: $+34.963 .877 .809$ 


\section{Introduction}

The growing interest in proton conducting solid oxide fuel cells (PC-SOFC) [1-4] research is principally due to their advantages compared to conventional oxygen-ion conducting solid oxide fuel cells (SOFCs): (1) their higher efficiency and fuel utilization, since protons react with oxygen in the cathode to form water diluting the air stream; and (2) the lower activation energy of proton transport together with the higher mobility of protons, which makes possible to reduce the operation temperature (500 $700{ }^{\circ} \mathrm{C}$ ) and permits the utilization of less expensive system components and increases their lifetime $[5,6]$.

Nowadays different proton conducting materials, as doped $\mathrm{SrCeO}_{3}, \mathrm{BaCeO}_{3}$ and $\mathrm{BaZrO}_{3}$ perovskites $[2,7,8] \mathrm{LaNbO}_{4}$ scheelite [9] and $\mathrm{La}_{5.5} \mathrm{WO}_{11.25-\delta}$ defective fluorite [10] are being investigated as promising electrolytes for PC-SOFCs. Among these, $\mathrm{La}_{5.5} \mathrm{WO}_{11.25-\delta}(\mathrm{LWO})$ compound combines essential properties for a final application, as it exhibits reasonable high values of predominant protonic conductivity below 800 ${ }^{\circ} \mathrm{C}$, low grain boundary resistance and high stability in operation conditions for long times under $\mathrm{CO}_{2}$ and $\mathrm{H}_{2} \mathrm{~S}$ containing atmospheres [11-13].

The use of LWO electrolyte requires compatible electrodes, both cathodes $[14,15]$ and anodes $[16,17]$. Concerning the cathodes, some recent works have studied different materials compatible with LWO electrolyte, obtaining the best performances for a $\mathrm{La}_{0.7} \mathrm{Sr}_{0.3} \mathrm{MnO}_{3}(\mathrm{LSM}) / \mathrm{LWO}$ composites (with a $\mathrm{Rp}$ at $750{ }^{\circ} \mathrm{C}$ of $3 \Omega \cdot \mathrm{cm}^{2}$ for a $50 / 50$ vol. $\%$ composite [18] or $8 \Omega \cdot \mathrm{cm}^{2}$ for a $60 / 40$ vol.\% composite [14]). The use of these composites based on mixing materials with electronic, ionic and protonic conducting pathways was focused on extending the three phase boundary (TPB) area along the thickness of the cathode, with the consequent improvement on cathode performance $[14,19-22]$. In the present work three different cathodes based on the well-known 
mixed ionic-electronic (MIEC) conductor $\mathrm{La}_{2} \mathrm{NiO}_{4+\delta}$ are investigated. The use of MIEC materials as cathodes in PC-SOFC introduce pathways to transfer part of the dissociated oxygen ions through the bulk of the cathode to the TPBs to react with the protons (Figure 1). Thus, although the reacting areas are limited to the TPBs, the oxygen pathways to the TPBs are greatly enlarged, and this reduces the polarization resistance $[23,24]$.

$\mathrm{La}_{2} \mathrm{NiO}_{4+\delta}$ is a perovskite-related mixed conductor oxide whose structure consists of $\mathrm{LaNiO}_{3-\delta}$ perovskite layers separated by a $\mathrm{La}_{2} \mathrm{O}_{2}$ rocksalt layer. It belongs to the Ruddlesden-Popper series $\mathrm{La}_{n+1} \mathrm{Ni}_{\mathrm{n}} \mathrm{O}_{3 \mathrm{n}+1}$ with $n=1$, where $n$ denotes the number of perovskite layers between each rock salt layer. $\mathrm{La}_{2} \mathrm{NiO}_{4+\delta}$ layered structure permits a great flexibility in the stoichiometry, as this compound can incorporate oxygen in the structure in interstitial positions $[25,26]$. Defect sites are located in the $\mathrm{La}_{2} \mathrm{O}_{2}$ rocksalt interlayers. The oxygen excess improves oxygen reduction and diffusion in the intermediate temperature (IT) range, $500-800{ }^{\circ} \mathrm{C}$, and it is predominant along the $a-b$ planes [27-29]. It has been reported that below $400{ }^{\circ} \mathrm{C}$ in oxidizing conditions, layered nickelates exhibit a predominant semiconductor-type electronic conductivity, via smallpollaron hopping of $p$-type carriers, with a smooth change to metallic-like conduction at high temperatures $[28,30]$. This change to metallic-like behaviour has been attributed to the hole concentration decrease due to the oxygen loss with the temperature [31, 32].

This work focuses on the study of MIEC cathode materials for LWO based PC-SOFCs:

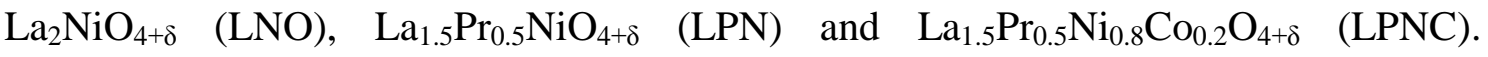
$\mathrm{La}_{2} \mathrm{NiO}_{4+\delta}$ was doped in the $\mathrm{A}$ and in both $\mathrm{A}$ and $\mathrm{B}$ positions (where $\mathrm{A}=\operatorname{Pr}$ and $\mathrm{B}=\mathrm{Co}$ ) in order to improve transport properties and electrocatalytic redox behavior, related to the multiple oxidation states possible for $\operatorname{Pr}$ and Co cations [33, 34]. After characterizing the powder and checking the compatibility with the LWO electrolyte, 
different symmetrical cells were prepared in order to study the electrochemical properties. Cathodes performance was finally improved by optimizing cathode sintering temperature.

\section{Experimental}

$\mathrm{La}_{2-\mathrm{x}} \mathrm{A}_{\mathrm{x}} \mathrm{Ni}_{1-\mathrm{y}} \mathrm{B}_{\mathrm{y}} \mathrm{O}_{4+\delta}(\mathrm{LANB}, \mathrm{A}=\mathrm{Pr}, \mathrm{x}=0,0.5$ and $\mathrm{B}=\mathrm{Co}, \mathrm{x}=0,0.2$ ) powders were prepared using the Pechini method [35]. Stoichiometric amounts of the different nitrates were mixed and dissolved in deionized water. Citric acid was added as a chelator and heated at $80{ }^{\circ} \mathrm{C}$. Ethylene glycol was added and heated up to $120{ }^{\circ} \mathrm{C}$ to obtain the reaction. After that, the gel was dried at $210{ }^{\circ} \mathrm{C}$ and then it was burned in a first step at $750{ }^{\circ} \mathrm{C}$. Finally the powder was pressed and calcined at $1350{ }^{\circ} \mathrm{C}$ for $4 \mathrm{~h}$. After sintering, powders were ball milled twice in acetone for $48 \mathrm{~h}$ in order to optimize the particle size of the powder, and the electrode microstructure as well (Figure S1). Inks for screen printing were prepared by using terpineol and ethylcellulose in a roller mixer.

The crystalline structure of the different materials was studied by X-ray diffraction (XRD). The measurements were carried out by a PANalytical Cubix fast diffractometer, using $\mathrm{CuK} \alpha_{1,2}$ radiation and an $\mathrm{X}^{\prime}$ Celerator detector in Bragg-Brentano geometry. XRD patterns were recorded in the $2 \theta$ range from $10^{\circ}$ to $90^{\circ}$ and analyzed using X'Pert Highscore Plus software.

Rectangular probes of the powders were uniaxially pressed at $125 \mathrm{MPa}$ for 1 minute and subsequently sintered for 5 hours at $1430{ }^{\circ} \mathrm{C}$ in air, achieving relative densities above 98\% (calculated by Archimedes method). Electrical conductivity measurements were conducted by standard four-point DC technique on the sintered bars using silver wire and paste for contacting. The measurements were carried out from 800 to $400{ }^{\circ} \mathrm{C}$, after stabilizing for $2 \mathrm{~h}$ at $800{ }^{\circ} \mathrm{C}$, by cooling down $\left(1{ }^{\circ} \mathrm{C} / \mathrm{min}\right)$ in different constant $p \mathrm{O}_{2}$ 
atmospheres (Linde calibrated gas mixtures checked by an YSZ oxygen sensor). The constant current was supplied by a programmable current source (Keithley 2601) and the voltage drop through the sample was detected by a multimeter (Keithley 3706).

LWO dense electrolytes ( 1 mm-thick) were obtained by uniaxally pressing the ballmilled LWO powder (Cerpotech commercial powder) at $~ 120 \mathrm{MPa}$ and finally firing at $1450{ }^{\circ} \mathrm{C}$ for $5 \mathrm{~h}$. Porous electrodes were obtained by screen-printing the inks on both sides of the LWO electrolytes and the thickness of the sintered electrodes was $\sim 30 \mu \mathrm{m}$. Firing temperature of the screen-printed cathode cells was $1150{ }^{\circ} \mathrm{C}$, and 1100 and 1050 ${ }^{\circ} \mathrm{C}$ in some cases, for $2 \mathrm{~h}$. The final size of symmetrical cells was $15.5 \mathrm{~mm}$ in diameter whereas cathodes were $\sim 9 \mathrm{~mm}$ in diameter.

Symmetrical cells with LANB / LWO / LANB cathodes were tested by electrochemical impedance spectroscopy (EIS) in two-point configuration with platinum current collector meshes. Input signal was $0 \mathrm{~V} \mathrm{DC}-20 \mathrm{mV} \mathrm{AC}$ in the $0.03-1 \cdot 10^{6} \mathrm{~Hz}$ frequency range (Solartron 1470E and a 1455A FRA module equipment). EIS measurements were performed in the $650-900{ }^{\circ} \mathrm{C}$ range, under wet atmospheres $(2.5 \%$ vol. $\mathrm{H}_{2} \mathrm{O}$ ) at different $\mathrm{pO}_{2}$ with a constant flow rate of $100 \mathrm{~mL} \cdot \mathrm{min}^{-1}$. The contribution of the LWO electrolyte was corrected from impedance spectra.

The as-sintered powders and fracture cross-sections of the sintered symmetrical cells (after electrochemical measurements) were analyzed by scanning electron microscopy (SEM) using a JEOL JSM6300 electron microscope.

\section{Results and discussion}

\subsection{Materials characterization and stability}


XRD patterns of the different sintered powders, $\mathrm{La}_{2} \mathrm{NiO}_{4+\delta}(\mathrm{LNO}), \mathrm{La}_{1.5} \mathrm{Pr}_{0.5} \mathrm{NiO}_{4+\delta}$ (LPN) and $\mathrm{La}_{1.5} \mathrm{Pr}_{0.5} \mathrm{Ni}_{0.8} \mathrm{Co}_{0.2} \mathrm{O}_{4+\delta}$ (LPNC), are represented in Figure 2a. For the three samples, all the diffraction peaks can be assigned to the $\mathrm{La}_{2} \mathrm{NiO}_{4+\delta}$ phase [36], i.e. no traces of other oxides can be detected to the limit of XRD. Therefore, Pr and Co are completely incorporated in the $\mathrm{La}_{2} \mathrm{NiO}_{4+\delta}$ structure in the concentration used here. Grain size distribution of the three different sintered powders can be observed in SEM images of Figure $2 \mathrm{~b}$. The distribution shows very similar grain sizes for all of them, ranging from 90 up to $180 \mathrm{~nm}$, that form agglomerates of 2, 1.5 and $1 \mu \mathrm{m}$ for LNO, LPN and LPNC, respectively. Thus the variation in the electrochemical performance among the different compounds should not be related to changes in the electrode microstructure.

The stability of the LNO, LPN and LPNC phases (in powder form) in air was investigated by comparing XRD patterns before and after a treatment in ambient air at $750{ }^{\circ} \mathrm{C}$ during two weeks (Figure $3 \mathrm{a}, \mathrm{b}$ and $\mathrm{c}$ ). The absence of new diffraction peaks after the treatment confirms the stability of these materials under this treatment. Before processing and testing the symmetrical cells, the compatibility of LNO with the LWO electrolyte phase was checked. Figure 4 shows XRD patterns of a mixture of LNO and LWO 50 vol.\% before and after being fired together at $1150{ }^{\circ} \mathrm{C}$ for $5 \mathrm{~h}$. All the diffraction peaks correspond to the LNO and the LWO phases. XRD patterns of LNO and LWO powders are also plotted in Figure 4, where it can be observed that LWO pattern presents a very small peak at $28.784^{\circ}$, which corresponds to small traces of $\mathrm{La}_{6} \mathrm{~W}_{2} \mathrm{O}_{15}$ phase [37]. The absence of reaction between LNO and LWO phases up to the highest temperature used for cathode preparation is confirmed by this lack of new peaks after the treatment at high temperature.

The transport properties were evaluated by measuring the total conductivity in air as a function of the temperature (Figure 5). The incorporation of $\mathrm{Pr}$ and Co increases the 
total conductivity of the undoped LNO material. In the measured range of temperatures (400-800 $\left.{ }^{\circ} \mathrm{C}\right)$ LPNC sample shows $p$-type semiconductor behaviour while LNO and LPN samples exhibit metallic-like conduction, ascribed to the depletion of the $p$-type carriers due to the oxygen loss with the temperature $[28,30]$. The transition temperature between the semiconductor and metal-like behaviours has been reported to be determined by the doping content and the oxygen non-stoichiometry of the compound $[38,39]$. Thus, while LNO and LPN samples reach this temperature below $400{ }^{\circ} \mathrm{C}$, in agreement with other works, LPNC sample presents this transition at temperatures higher than $800{ }^{\circ} \mathrm{C}$. The shift to high temperatures of $p$-type behaviour for the LPNC compound can be ascribed to the very high density of charge carriers (holes) of this compound and the lower oxygen loss at temperatures below $800{ }^{\circ} \mathrm{C}$ (See supporting information, Figure S2).

\subsection{Cathode testing on LWO electrolyte}

Symmetrical cells of the different powders were prepared on dense LWO electrolytes. The cathode porosity as well as electrolyte density can be observed in the cross-section image of the LPN cathode sintered at $1150{ }^{\circ} \mathrm{C}$ (Figure 6). The cathode looks very porous with relatively large surface area and shows a similar morphology as state-ofthe-art SOFC cathodes. Furthermore, the interface with the electrolyte is clean, with no visible reaction layers.

The electrochemical behavior of the three different cathodes sintered at $1150{ }^{\circ} \mathrm{C}$ was studied by EIS using symmetric cells. The polarization resistances (Rp) recorded in wet $\left(2.5 \% \mathrm{H}_{2} \mathrm{O}\right)$ air is displayed as a function of temperature in Figure 7. The electrochemical performance is notably improved by the incorporation of $\mathrm{Pr}$ and $\mathrm{Co}$, for instance, a $\mathrm{Rp}$ value of $5.03 \Omega \cdot \mathrm{cm}^{2}$ is achieved at $750{ }^{\circ} \mathrm{C}$ for $\mathrm{LNO}$ while the doped compounds show values of $1.03 \Omega \cdot \mathrm{cm}^{2}$ and $0.93 \Omega \cdot \mathrm{cm}^{2}$ for LNP and LPNC, 
respectively. The activation energy $\left(E_{a}\right)$ of the LNO remains constant $(1.47 \mathrm{eV})$ when the Pr dopant is introduced in the A position (LPN sample). However, when the Co dopant is also introduced in the B position together with the $\operatorname{Pr}, E a$ is slightly reduced $(1.44 \mathrm{eV})$. For this reason the best electrochemical properties are achieved for the LPNC cathode, which behaves somewhat better at low temperatures than the LPN electrode. The better performance of the doped compounds could be linked to the higher total conductivity and the reported catalytic effect of $\mathrm{Co}$ and $\operatorname{Pr}$ on oxygen reduction electrocatalysts $[40,41]$.

The impedance spectra recorded at $750{ }^{\circ} \mathrm{C}$ in wet air for the three cathodes sintered at $1150^{\circ} \mathrm{C}$ are represented in Figure 8a and b (Nyquist and Bode plots, respectively). One or two different contributions (one or two separated arcs) can be distinguished. Thus impedance data were modeled following an equivalent circuit composed of one or two parallel R $\|$ CPE elements, in series. Figure 8c-d-e also depict the modeled resistances (R) obtained from EIS spectra of LNO (Figure 8c), LPN (Figure 8d) and LPNC (Figure 8e) cathodes measured in wet air. LNO cathode shows one contribution at high frequencies $(\mathrm{HF}, 2 \mathrm{MHz})$ and another at medium frequencies $(\mathrm{MF}, 0.5-10 \mathrm{kHz})$, being this last one the highest and limiting the cathode performance [42]. The impedance spectrum for LNO (Figure 8a) shows an additional but very small contribution at low frequencies (LF), which is only slightly significant at high temperature, and thus the modeling results for this LF contribution are not plotted in Figure 8c. When the cathode composition is doped (with $\operatorname{Pr}$ and with Pr and Co), the HF contribution disappears while the MF contribution becomes smaller, giving rise to a better performance of the cathode. As mentioned above, this behavior is associated with the better transport properties of the doped compounds, which drastically reduces the HF contributions, typically associated with the total transport of the cathode materials. The cathode 
material doped with both Pr and Co (LPNC) shows an additional but less pronounced improvement in the MF contribution, with respect to LPN cathode.

The resistance dependency with $p \mathrm{O}_{2}$ provides information about the type of the species involved in the electrode reaction (equation 1): [23, 43]

$$
R_{i} \propto p O_{2}^{-m_{i}}
$$

A further analysis of the modeling results may allow gaining more insight into the different rate-limiting-steps in the cathode operation. Namely, Figure 9(a-b-c) presents the calculated resistances and Figure 9 (d-e-f) displays the capacitances for three electrodes as a function of temperature.

The HF associated processes only appear in the LNO cathode with very low associated capacitances $\left(4 \times 10^{-6} \mathrm{~F} / \mathrm{cm}^{2}\right)$ and $m$ values close to $1 / 4$. This term can be associated specifically to the transport of the bulk LNO, which has the $p \mathrm{O}_{2}$ dependency $-1 / 4$ as corresponds to a $p$-type electronic conductor. [23, 24] The MF associated processes, limiting the three measured cathodes, have $m$ values close to $1 / 4(0.28,0.26$ and 0.20 for LNO, LPN and LPNC respectively). This $p \mathrm{O}_{2}$ dependency and capacities of around $10^{-3} \mathrm{~F} / \mathrm{cm}^{2}$ can be related to ionic transport from TPB interface towards the electrolyte and not to electrode-electrolyte interfacial processes, since no $\mathrm{pO}_{2}$ dependence would be expected in that case $[42,44,45]$.

Finally and in order to further optimized LPNC cathode performance, different sintering temperatures were analyzed. Figure 10 summarizes Rp of LPNC cathodes sintered at 1150,1100 and $1050{ }^{\circ} \mathrm{C}$. The best performance is obtained for cathode sintered at 1050 ${ }^{\circ} \mathrm{C}\left(\mathrm{Rp}=0.62 \Omega \cdot \mathrm{cm}^{2}\right.$ at $750{ }^{\circ} \mathrm{C}$ in wet air) while the other two different temperatures result in similar performances (around $0.93 \Omega \cdot \mathrm{cm}^{2}$ ). As similar impedance spectra were obtained despite the sintering temperature and by taking into account that the overall 
transport of the material is not changed, this improvement in the electrode sintered at lower temperature can be ascribed to the higher porosity and lower grain sizes of the cathode. Thus the electrocatalysts surface area available for surface reactions is enlarged while the bounding among grains is preserved.

\section{Conclusions}

$\mathrm{La}_{2} \mathrm{NiO}_{4+\delta}$ was investigated as cathode for PC-SOFC based on La5.5 $\mathrm{WO}_{11.25-\delta}$ electrolyte. Once probed the chemical compatibility between cathode and electrolyte phases $\left(\mathrm{La}_{2} \mathrm{NiO}_{4+\delta}\right.$ and $\mathrm{La}_{5.5} \mathrm{WO}_{11.25-\delta}$ respectively) the electrochemical properties of the cathode were improved by partially substituting La and/or Ni. Specifically $\mathrm{La}_{1.5} \mathrm{Pr}_{0.5} \mathrm{NiO}_{4+\delta}$ and $\mathrm{La}_{1.5} \operatorname{Pr}_{0.5} \mathrm{Ni}_{0.8} \mathrm{Co}_{0.2} \mathrm{O}_{4+\delta}$ materials were considered and showed improved total conductivity and reduced polarization resistance, when tested as cathode in symmetrical cells. A final microstructure optimization of $\mathrm{La}_{1.5} \operatorname{Pr}_{0.5} \mathrm{Ni}_{0.8} \mathrm{Co}_{0.2} \mathrm{O}_{4+\delta}$ was completed by varying the firing temperature of the cathode.

The cathode performance of these mixed conductors was found to be limited by medium frequencies associated processes and electrochemical properties are better than those of previously tested composites based on $\mathrm{La}_{5.5} \mathrm{WO}_{11.25-\delta}$ and pure electronic conductors. $\mathrm{La}_{1.5} \operatorname{Pr}_{0.5} \mathrm{Ni}_{0.8} \mathrm{Co}_{0.2} \mathrm{O}_{4+\delta}$ cathode sintered at $1050{ }^{\circ} \mathrm{C}$ exhibits the best electrochemical performance on a $\mathrm{La}_{5.5} \mathrm{WO}_{11.25-\delta}$-based PC-SOFC, achieving $\mathrm{Rp}=0.62$ $\Omega \cdot \mathrm{cm}^{2}$ at $750^{\circ} \mathrm{C}$ in wet air.

\section{Acknowledgements}

Funding from European Union (FP7 Project EFFIPRO - Grant Agreement 227560), the Spanish Government (ENE2011-24761, SEV-2012-0267, BES-2012-053180 and CSIC 
Intramural 200880I093 grants) is kindly acknowledged. The authors thank M. Fabuel for sample preparation.

\section{Figure Captions}

Figure 1: Schematic diagram of MIEC cathode reaction mechanisms for a LWO proton conducting electrolyte

Figure 2: (a) XRD patterns of $\mathrm{La}_{2} \mathrm{NiO}_{4+\delta}$ (LNO), $\mathrm{La}_{1.5} \mathrm{Pr}_{0.5} \mathrm{NiO}_{4+\delta}$ (LPN) and $\mathrm{La}_{1.5} \mathrm{Pr}_{0.5} \mathrm{Ni}_{0.8} \mathrm{Co}_{0.2} \mathrm{O}_{4+\delta}$ (LPNC) and (b) SEM image

Figure 3: XRD patterns of (a) LNO, (b) LPN and (c) LPNC before and after stability test in air.

Figure 4: XRD patterns of $\mathrm{LWO}, \mathrm{La}_{2} \mathrm{NiO}_{4+\delta}$ and a $50 \%$ mixture of both phases at room temperature and after being calcined at $1150^{\circ} \mathrm{C}$ for $5 \mathrm{~h}$.

Figure 5: Total conductivity as a function of temperature of LNO, LPN and LPNC.

Figure 6: SEM analysis of the fracture cross-section of a cell (after electrochemical testing) consisting of a LWO dense electrolyte coated with LPNC cathode.

Figure 7: Polarization resistance as a function of 1000/T in wet synthetic air for $\mathrm{La}_{2} \mathrm{NiO}_{4+\delta}, \mathrm{La}_{1.5} \mathrm{Pr}_{0.5} \mathrm{NiO}_{4+\delta}$ and $\mathrm{La}_{1.5} \mathrm{Pr}_{0.5} \mathrm{Ni}_{0.8} \mathrm{Co}_{0.2} \mathrm{O}_{4+\delta}$

Figure 8: Impedance spectra, (a) Nyquist and (b) Bode plots, of $\mathrm{La}_{2} \mathrm{NiO}_{4+\delta}$, $\mathrm{La}_{1.5} \operatorname{Pr}_{0.5} \mathrm{NiO}_{4+\delta}$ and $\mathrm{La}_{1.5} \operatorname{Pr}_{0.5} \mathrm{Ni}_{0.8} \mathrm{Co}_{0.2} \mathrm{O}_{4+\delta}$ measured at $750{ }^{\circ} \mathrm{C}$ in wet synthetic air. Modeled resistances as a function of temperature of (c) $\mathrm{La}_{2} \mathrm{NiO}_{4+\delta}$, (d) $\mathrm{La}_{1.5} \mathrm{Pr}_{0.5} \mathrm{NiO}_{4+\delta}$ and (e) $\mathrm{La}_{1.5} \mathrm{Pr}_{0.5} \mathrm{Ni}_{0.8} \mathrm{Co}_{0.2} \mathrm{O}_{4+\delta}$ 
Figure 9: Modeled resistances of (a) $\mathrm{La}_{2} \mathrm{NiO}_{4+\delta}$, (b) $\mathrm{La}_{1.5} \mathrm{Pr}_{0.5} \mathrm{NiO}_{4+\delta}$ and (c) $\mathrm{La}_{1.5} \mathrm{Pr}_{0.5} \mathrm{Ni}_{0.8} \mathrm{Co}_{0.2} \mathrm{O}_{4+\delta}$ and capacitances of (d) $\mathrm{La}_{2} \mathrm{NiO}_{4+\delta}$, (e) $\mathrm{La}_{1.5} \mathrm{Pr}_{0.5} \mathrm{NiO}_{4+\delta}$ and (f) $\mathrm{La}_{1.5} \mathrm{Pr}_{0.5} \mathrm{Ni}_{0.8} \mathrm{Co}_{0.2} \mathrm{O}_{4+\delta}$ as a function of the $p \mathrm{O}_{2}$ (wet gas environment).

Figure 10: $\mathrm{Rp}$ as a function of $1000 / \mathrm{T}$ of $\mathrm{La}_{1.5} \operatorname{Pr}_{0.5} \mathrm{Ni}_{0.8} \mathrm{Co}_{0.2} \mathrm{O}_{4+\delta}$ sintered at 1050,1100 and $1150^{\circ} \mathrm{C}$ 


\section{References}

[1] K.D. Kreuer, Annual Review of Materials Research 33 (2003) 333-359.

[2] H. Iwahara, Solid State Ionics 77 (1995) 289-298.

[3] H. Iwahara, Y. Asakura, K. Katahira, M. Tanaka, Solid State Ionics 168 (2004) 299-310.

[4] W.G. Coors, Journal of Power Sources 118 (2003) 150-156.

[5] N. Bonanos, B. Ellis, M.N. Mahmood, Solid State Ionics 44 (1991) 305-311.

[6] J.M. Serra, W.A. Meulenberg, Journal of the American Ceramic Society 90 (2007) 2082-2089.

[7] N. Bonanos, K.S. Knight, B. Ellis, Solid State Ionics 79 (1995) 161-170.

[8] S. Escolastico, M. Ivanova, C. Solis, S. Roitsch, W.A. Meulenberg, J.M. Serra, Rsc Advances 2 (2012) 4932-4943.

[9] R. Haugsrud, T. Norby, Nature Materials 5 (2006) 193-196.

[10] R. Haugsrud, C. Kjolseth, Journal of Physics and Chemistry of Solids 69 (2008) 1758-1765.

[11] C. Solis, S. Escolastico, R. Haugsrud, J.M. Serra, Journal of Physical Chemistry C 115 (2011) 11124-11131.

[12] S. Escolastico, C. Solis, J.M. Serra, Solid State Ionics 216 (2012) 31-35.

[13] S. Escolastico, V.B. Vert, J.M. Serra, Chemistry of Materials 21 (2009) 30793089 .

[14] C. Solis, L. Navarrete, S. Roitsch, J.M. Serra, Journal of Materials Chemistry 22 (2012) 16051-16059.

[15] V. Besikiotis, R. Strandbakke, T. Norby, Journal of the electrochemical society Submitted.

[16] C. Solis, V.B. Vert, M. Balaguer, S. Escolastico, S. Roitsch, J.M. Serra, ChemSusChem 5 (2012) 2155 - 2158.

[17] M. Balaguer, C. Solis, F. Bozza, N. Bonanos, J.M. Serra, Journal of Materials Chemistry A 1 (2013) 3004-3007.

[18] E. Quarez, K.V. Kravchyk, O. Joubert, Solid State Ionics 216 (2012) 19-24.

[19] C. Solis, V.B. Vert, M. Fabuel, J.M. Serra, Journal of Power Sources 196 (2011) 9220-9227.

[20] E. Fabbri, L. Bi, D. Pergolesi, E. Traversa, Energy \& Environmental Science 4 (2011) 4984-4993.

[21] E. Fabbri, L. Bi, D. Pergolesi, E. Traversa, Advanced Materials 24 (2012) 195208.

[22] V.B. Vert, C. Solis, J.M. Serra, Fuel Cells 11 (2011) 81-90.

[23] R.R. Peng, T.Z. Wu, W. Liu, X.Q. Liu, G.Y. Meng, Journal of Materials Chemistry 20 (2010) 6218-6225. 
[24] A. Grimaud, F. Mauvy, J.M. Bassat, S. Fourcade, M. Marrony, J.C. Grenier, Journal of Materials Chemistry 22 (2012) 16017-16025.

[25] R. Sayers, R.A. De Souza, J.A. Kilner, S.J. Skinner, Solid State Ionics 181 (2010) 386-391.

[26] J.D. Jorgensen, B. Dabrowski, S. Pei, D.R. Richards, D.G. Hinks, Physical Review B 40 (1989) 2187-2199.

[27] M. Burriel, G. Garcia, J. Santiso, J.A. Kilner, J.C.C. Richard, S.J. Skinner, Journal of Materials Chemistry 18 (2008) 416-422.

[28] V.V. Kharton, A.A. Yaremchenko, A.L. Shaula, M.V. Patrakeev, E.N. Naumovich, D.I. Loginovich, J.R. Frade, F.M.B. Marques, Journal of Solid State Chemistry 177 (2004) 26-37.

[29] M. Burriel, J. Santiso, M.D. Rossell, G. Van Tendeloo, A. Figueras, G. Garcia, Journal of Physical Chemistry C 112 (2008) 10982-10987.

[30] H. Tamura, A. Hayashi, Y. Ueda, Physica C 216 (1993) 83-88.

[31] J.M. Bassat, P. Odier, J.P. Loup, Journal of Solid State Chemistry 110 (1994) 124-135.

[32] K. Ishikawa, W. Shibata, K. Watanabe, T. Isonaga, M. Hashimoto, Y. Suzuki, Journal of Solid State Chemistry 131 (1997) 275-281.

[33] M. Balaguer, C. Solis, J.M. Serra, Chemistry of Materials 23 (2011) 2333-2343.

[34] M. Balaguer, C. Solis, J.M. Serra, Journal of Physical Chemistry C 116 (2012) 7975-7982.

[35] J.M. Serra, V.B. Vert, M. Betz, V.A.C. Haanappel, W.A. Meulenberg, F. Tietz, Journal of the Electrochemical Society 155 (2008) B207-B214.

[36] A. Aguadero, J.A. Alonso, M.J. Martinez-Lope, M.T. Fernandez-Diaz, M.J. Escudero, L. Daza, Journal of Materials Chemistry 16 (2006) 3402-3408.

[37] J.S. M. Ivanova, J. M. Serra, C. Solis, W. A. Meulenberg, W. Fischer, S. Roitsch, H.-P. Buchkrmer, Chemistry and Materials Research 2 (2012) 56.

[38] Y. Takeda, R. Kanno, M. Sakano, O. Yamamoto, M. Takano, Y. Bando, H. Akinaga, K. Takita, J.B. Goodenough, Materials Research Bulletin 25 (1990) 293-306.

[39] J.M. Bassat, J.P. Loup, P. Odier, Journal of Physics-Condensed Matter 6 (1994) 8285-8293.

[40] J.M. Serra, V.B. Vert, Journal of the Electrochemical Society 157 (2010) B1349B1357.

[41] J.M. Serra, V.B. Vert, ChemSusChem 2 (2009) 957-961.

[42] S.B. Adler, Chemical Reviews 104 (2004) 4791-4843.

[43] F. He, T.Z. Wu, R.R. Peng, C.R. Xia, Journal of Power Sources 194 (2009) 263268.

[44] R. Baker, J. Guindet, M. Kleitz, Journal of the Electrochemical Society 144 (1997) 2427-2432.

[45] C. Solis, L. Navarrete, F. Bozza, N. Bonanos, J.M. Serra, ChemSusChem Submitted. 
Figures

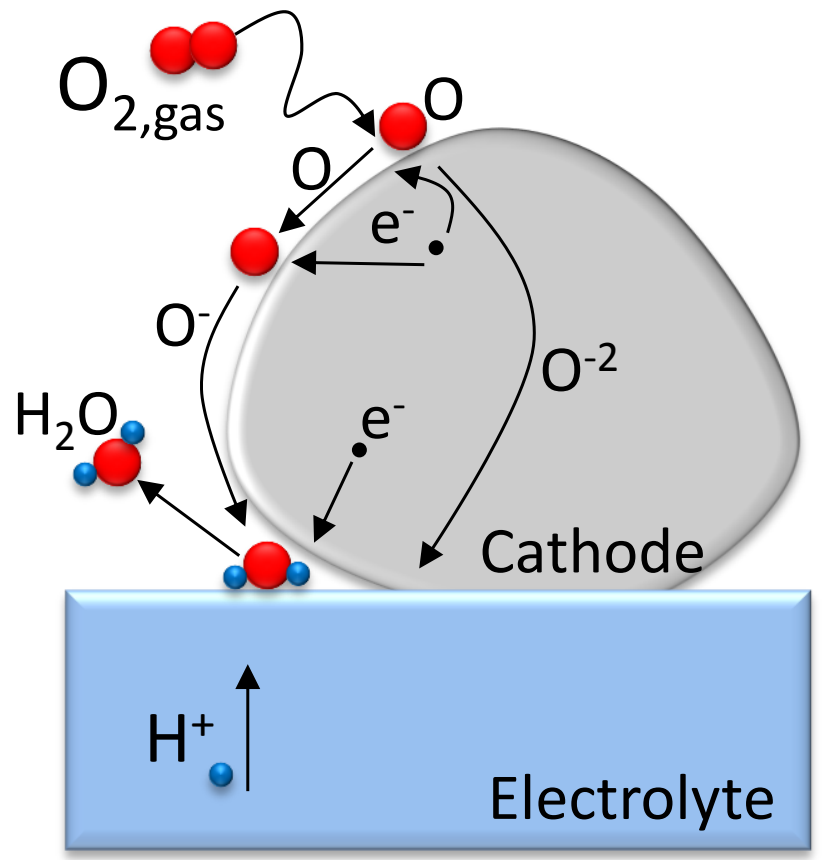

Figure 1 


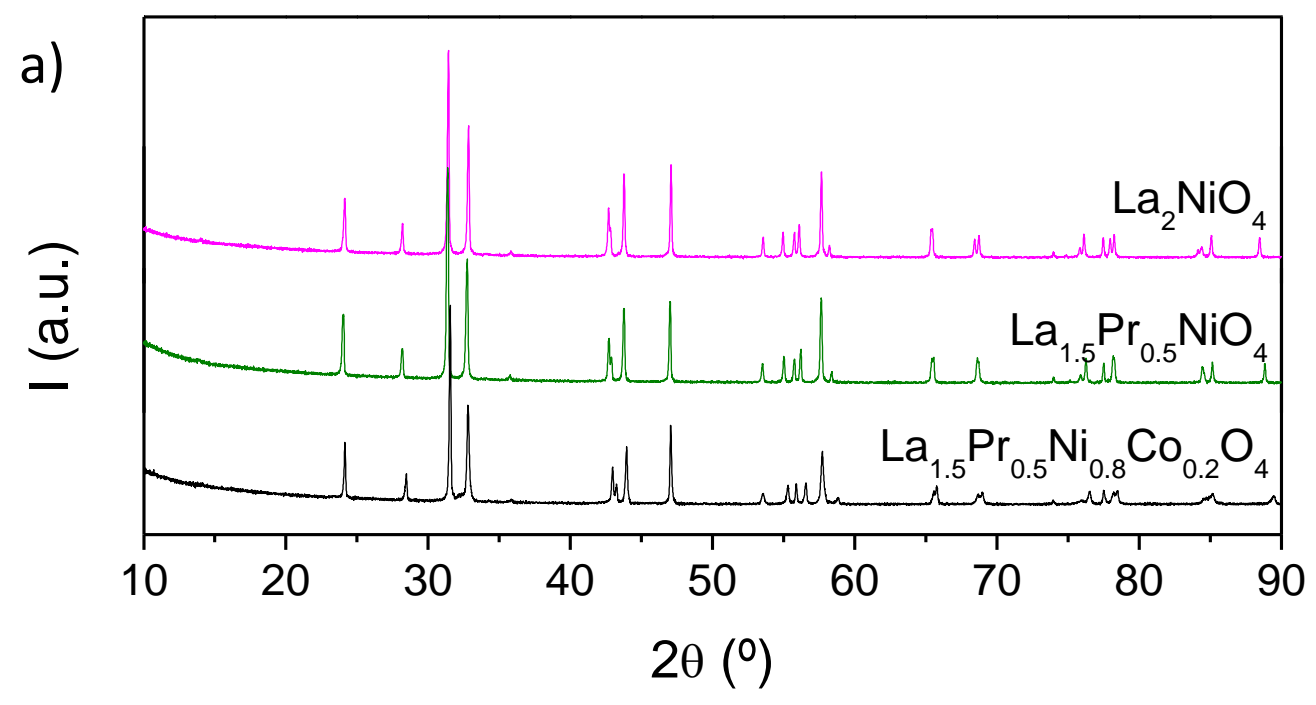

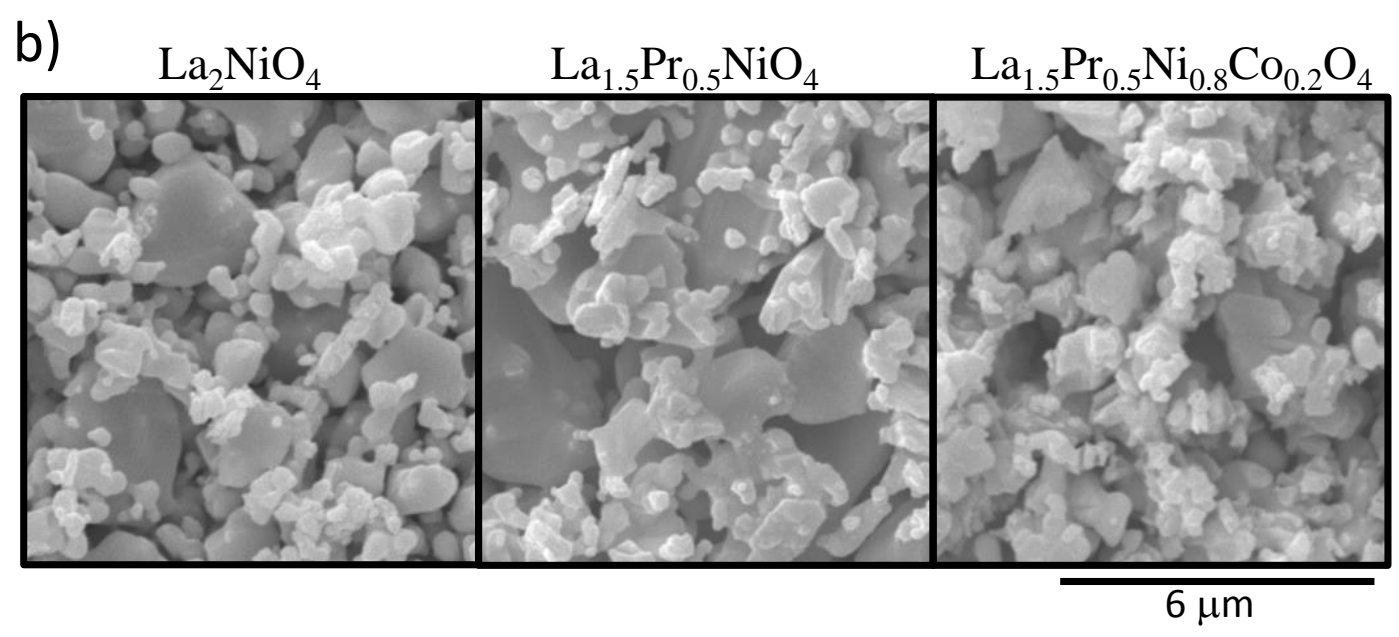

Figure 2 

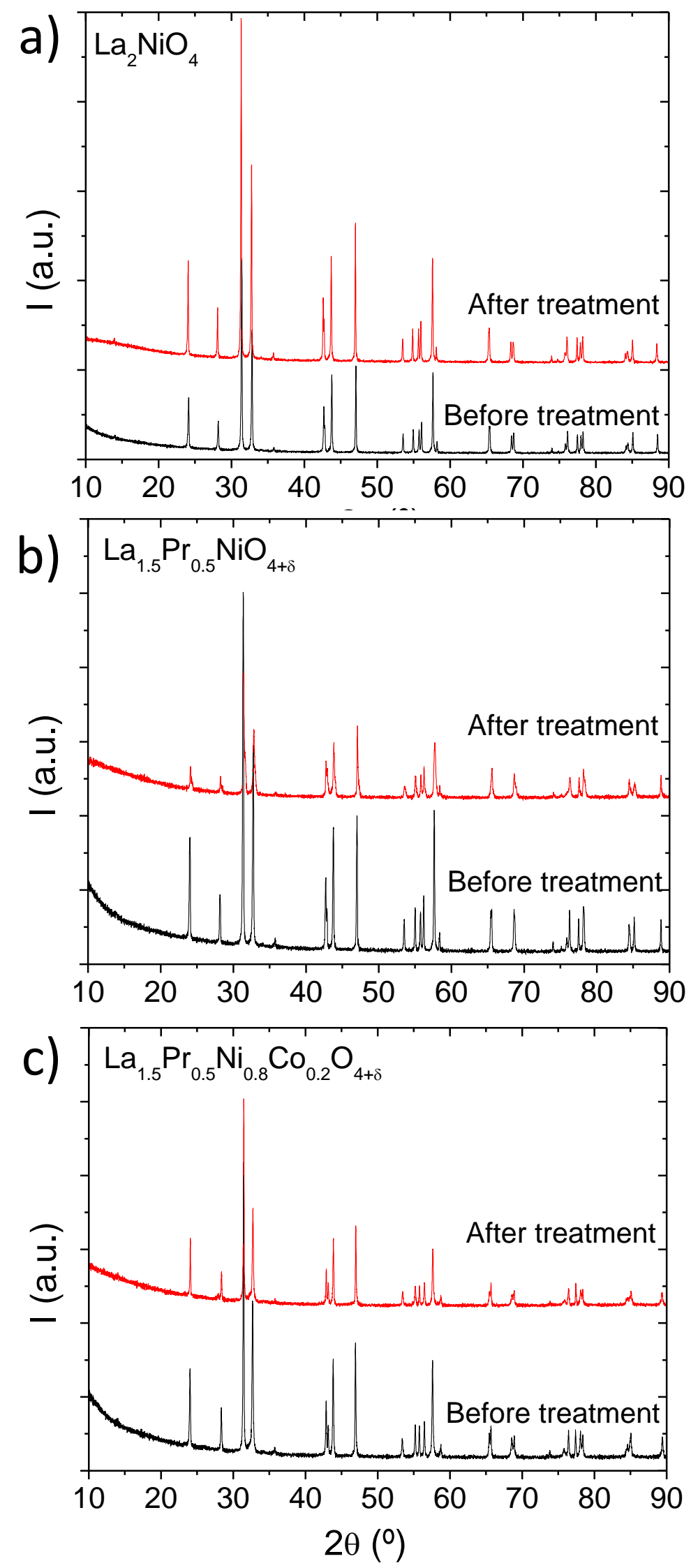

Figure 3 


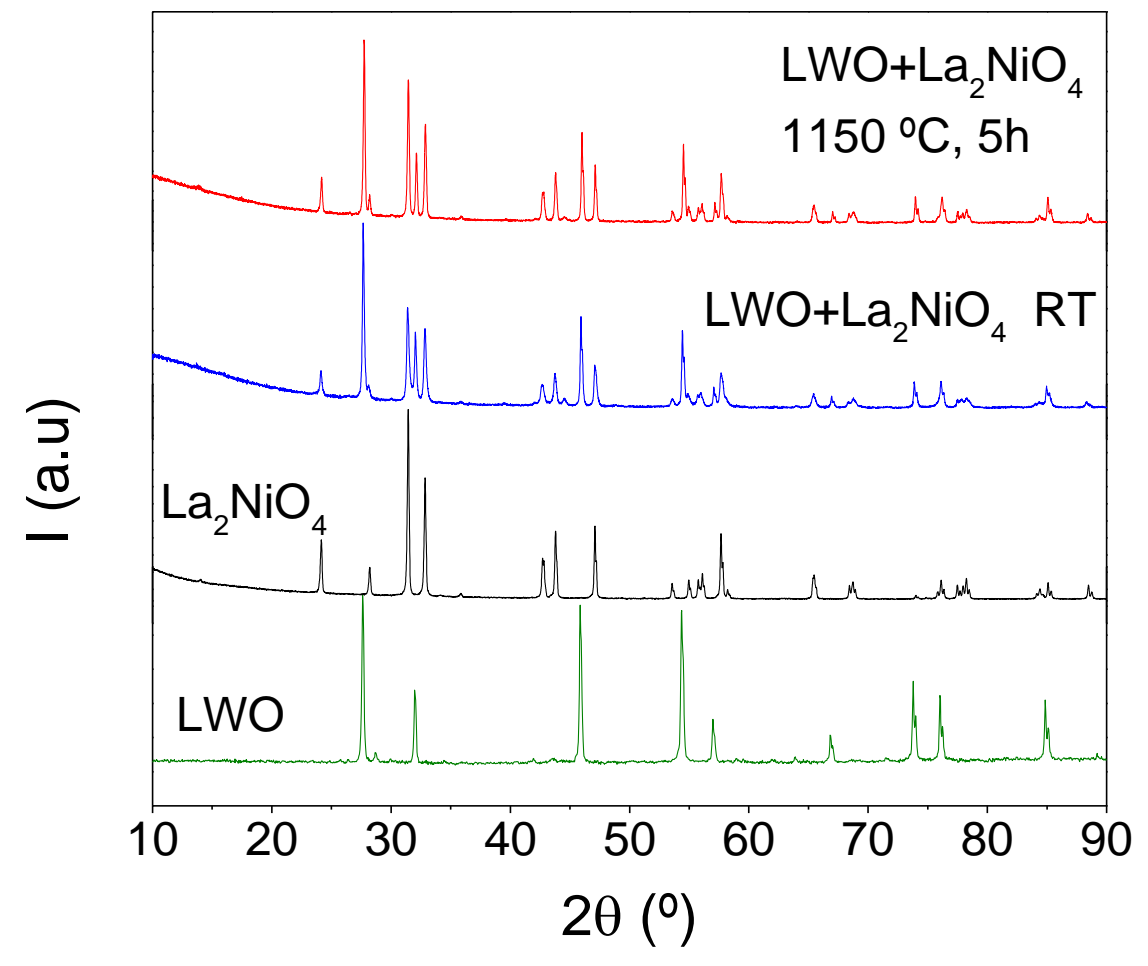

Figure 4 


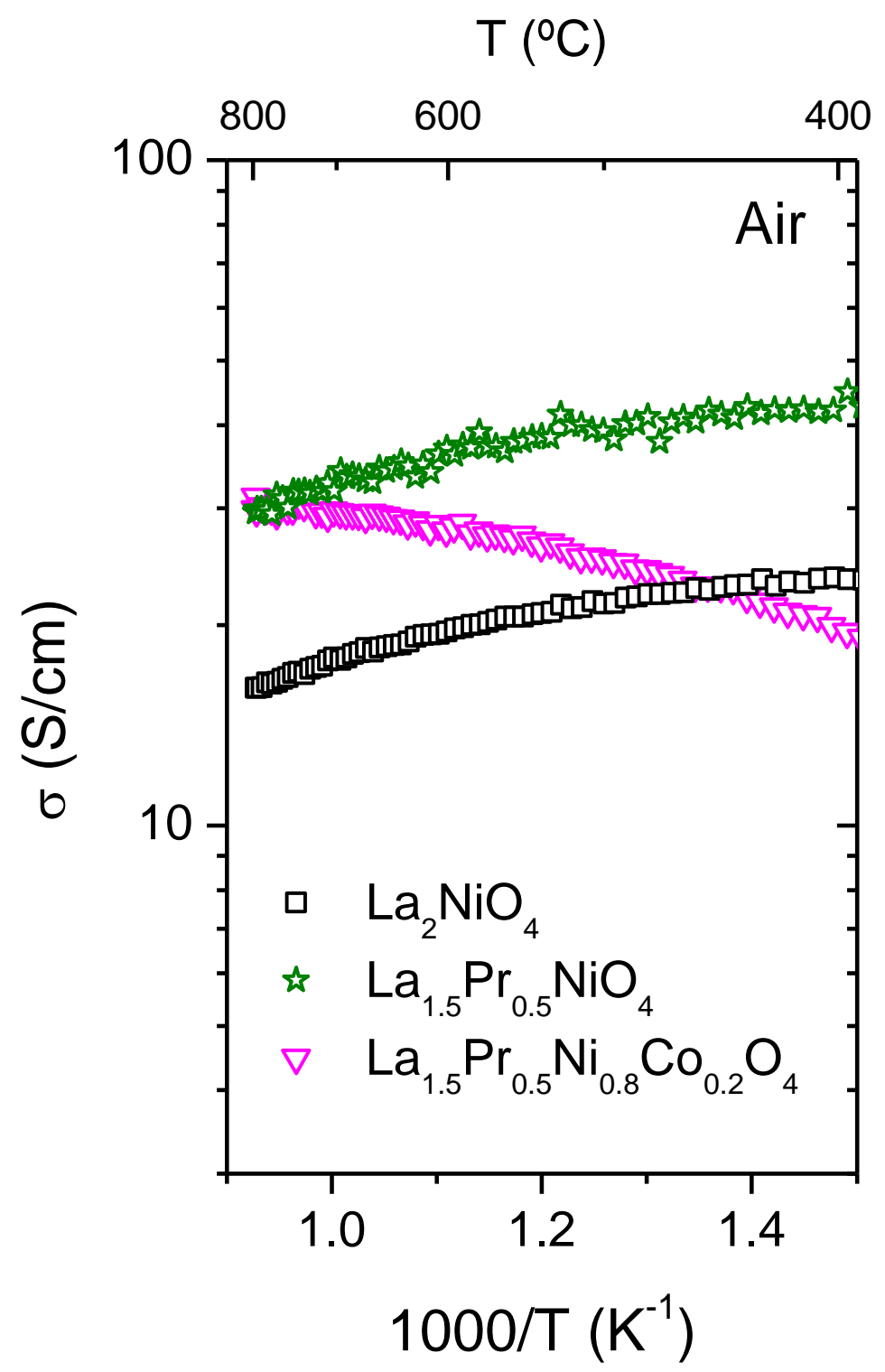

Figure 5 


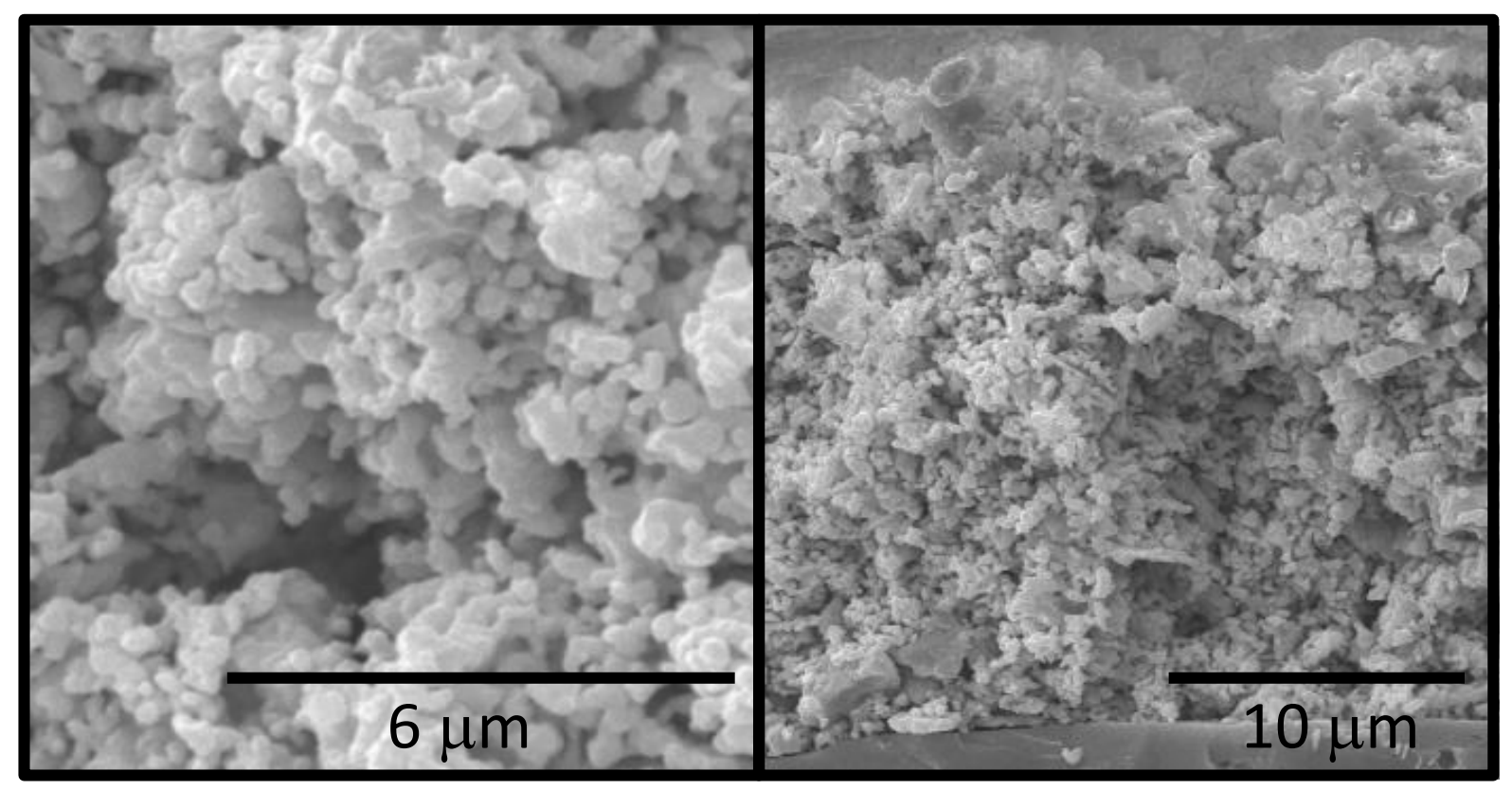

Figure 6 


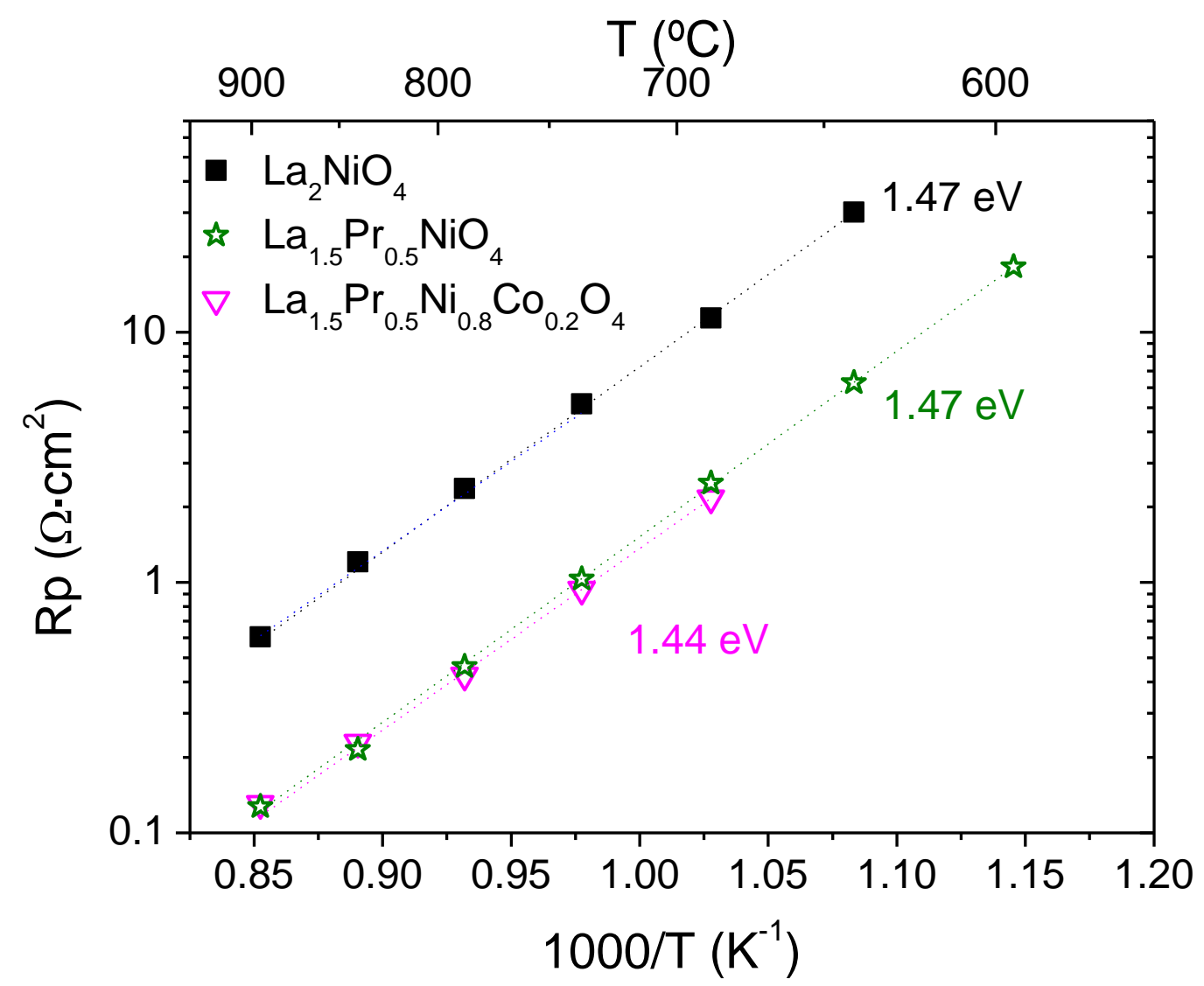

Figure 7 
a)



c)

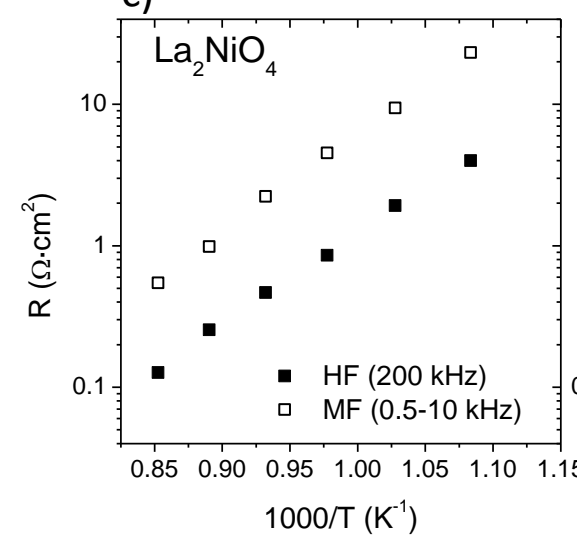

b)

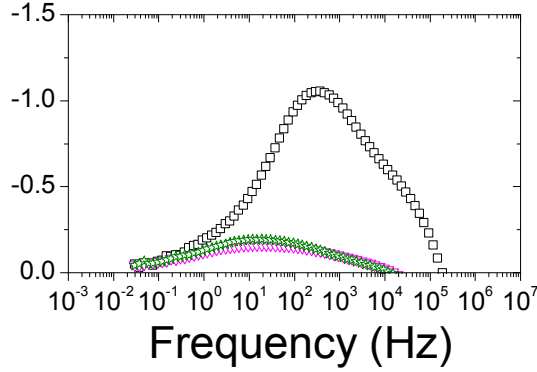

e)

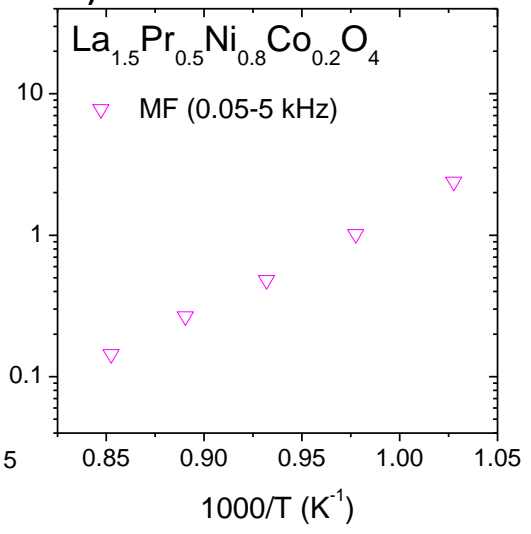

Figure 8 
a)
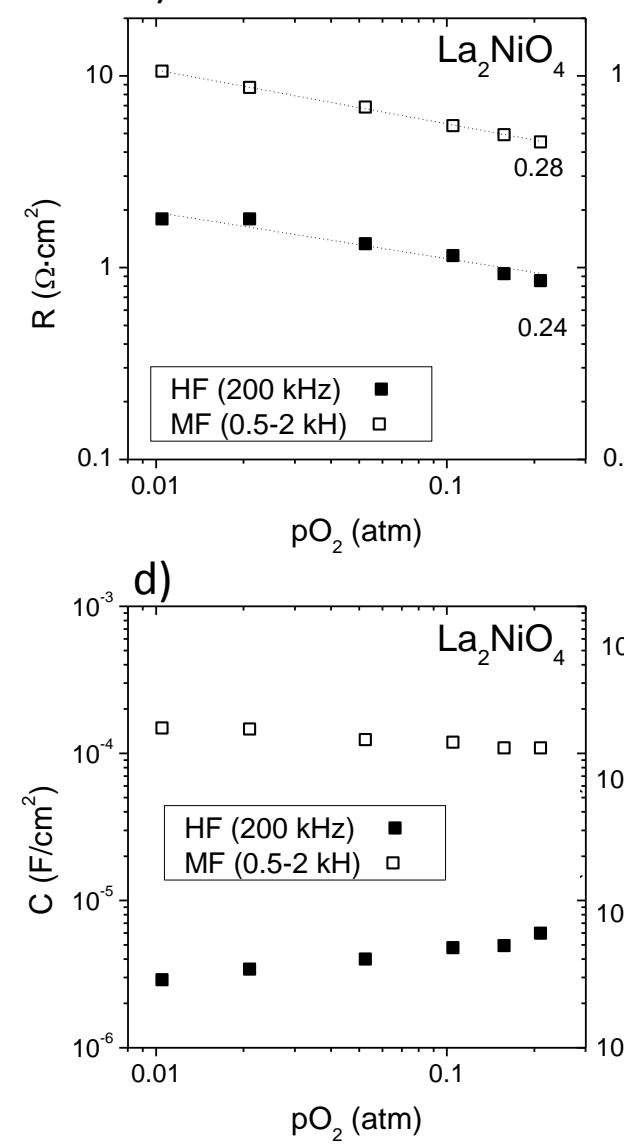

b)

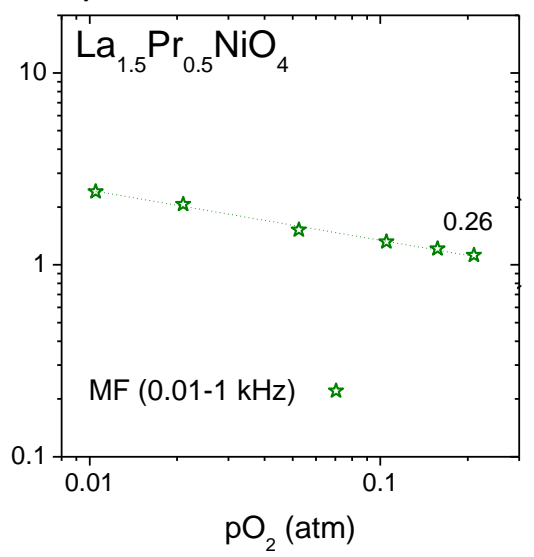

e)



c)

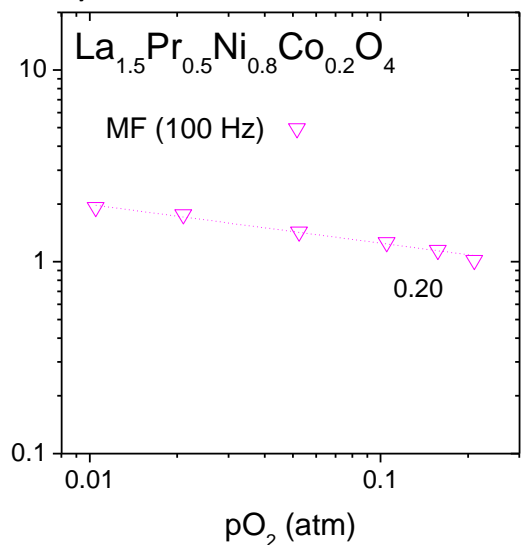

f)

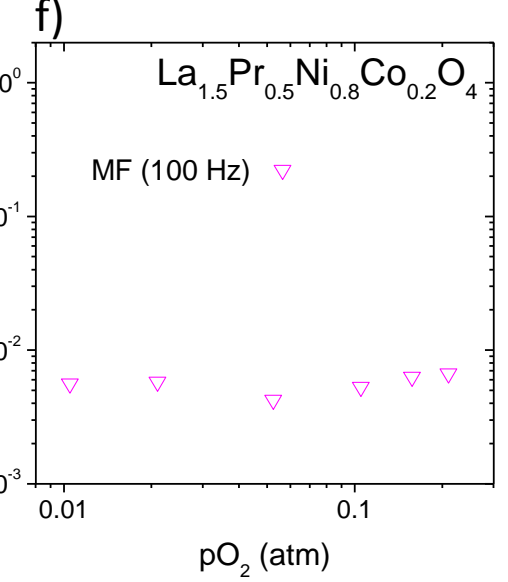

Figure 9 




Figure 10 


\section{Supporting Information}

Figure S1: SEM analysis of the samples in powder form before and after ball-milling. The milled samples were used for the preparation of the screen-printing inks.

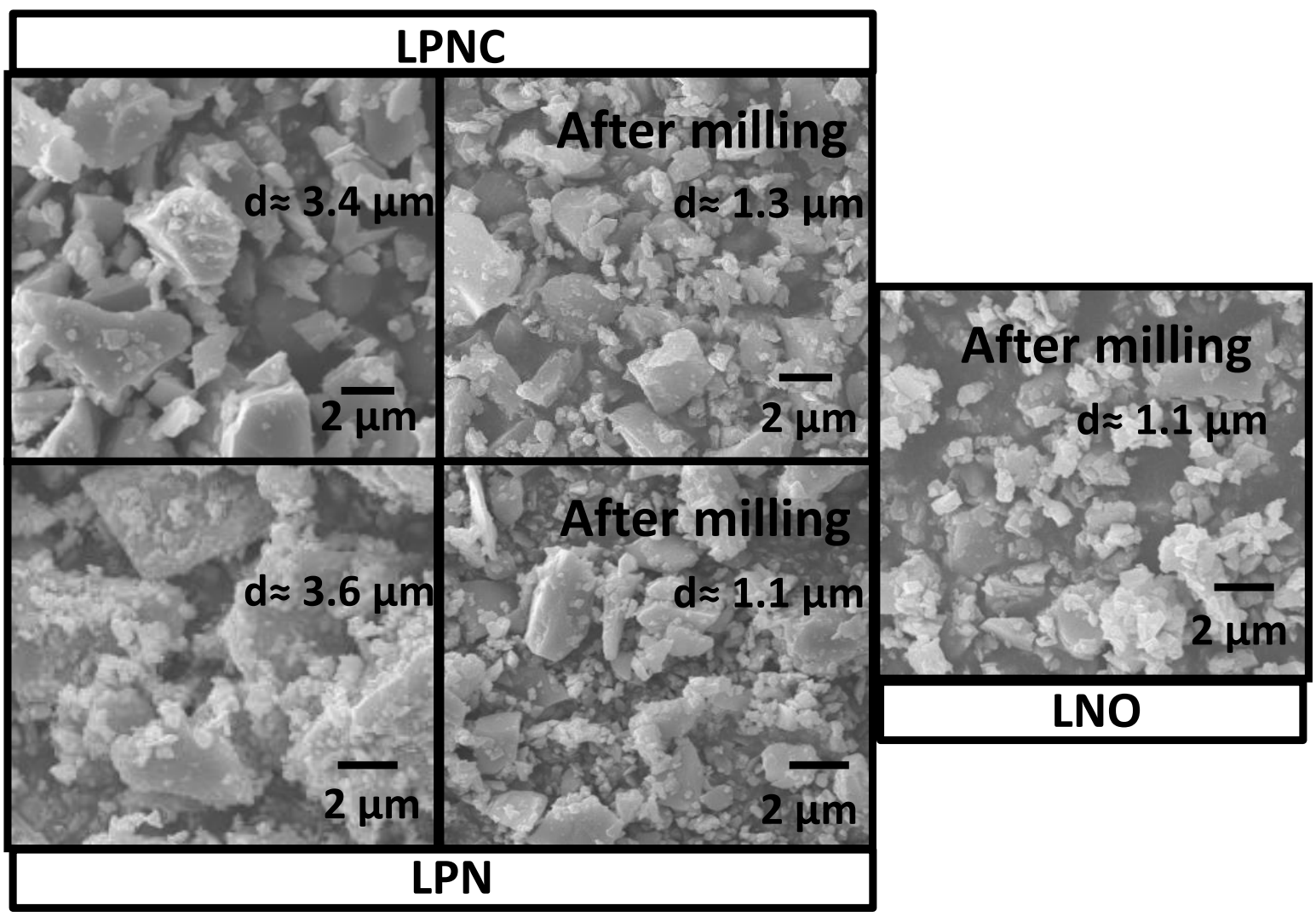


Figure S2: Thermo-gravimetric (TG) measurements (weight loss evolution) were performed on a Metler-Toledo StarE balance under dry air flow in the range 300-1273 $\mathrm{K}$ following a heating ramp of $5 \mathrm{~K} / \mathrm{min}$. The mass percentage evolution is showed in the graph. Up to $300{ }^{\circ} \mathrm{C}$ the weight decreases due to surface humidity loss. At higher temperatures, the weight loss is only ascribed to the oxygen release. The figure inset shows the weight loss evolution as function of temperature after subtracting the mass decrease ascribed to the adsorbed water of the powder. There can be observed the higher amount of oxygen release of LNO compared to that of LPN. LPNC shows the smaller amount of oxygen released at the same temperatures, although all samples present oxygen release. Consequently, the different conductivity behaviours at high temperatures can not be only related to the oxygen release. It has to be taken into account the different charge carrier densities of the materials. LPNC has higher p-type electronic carriers and the oxygen release is not enough to diminish the total conductivity.

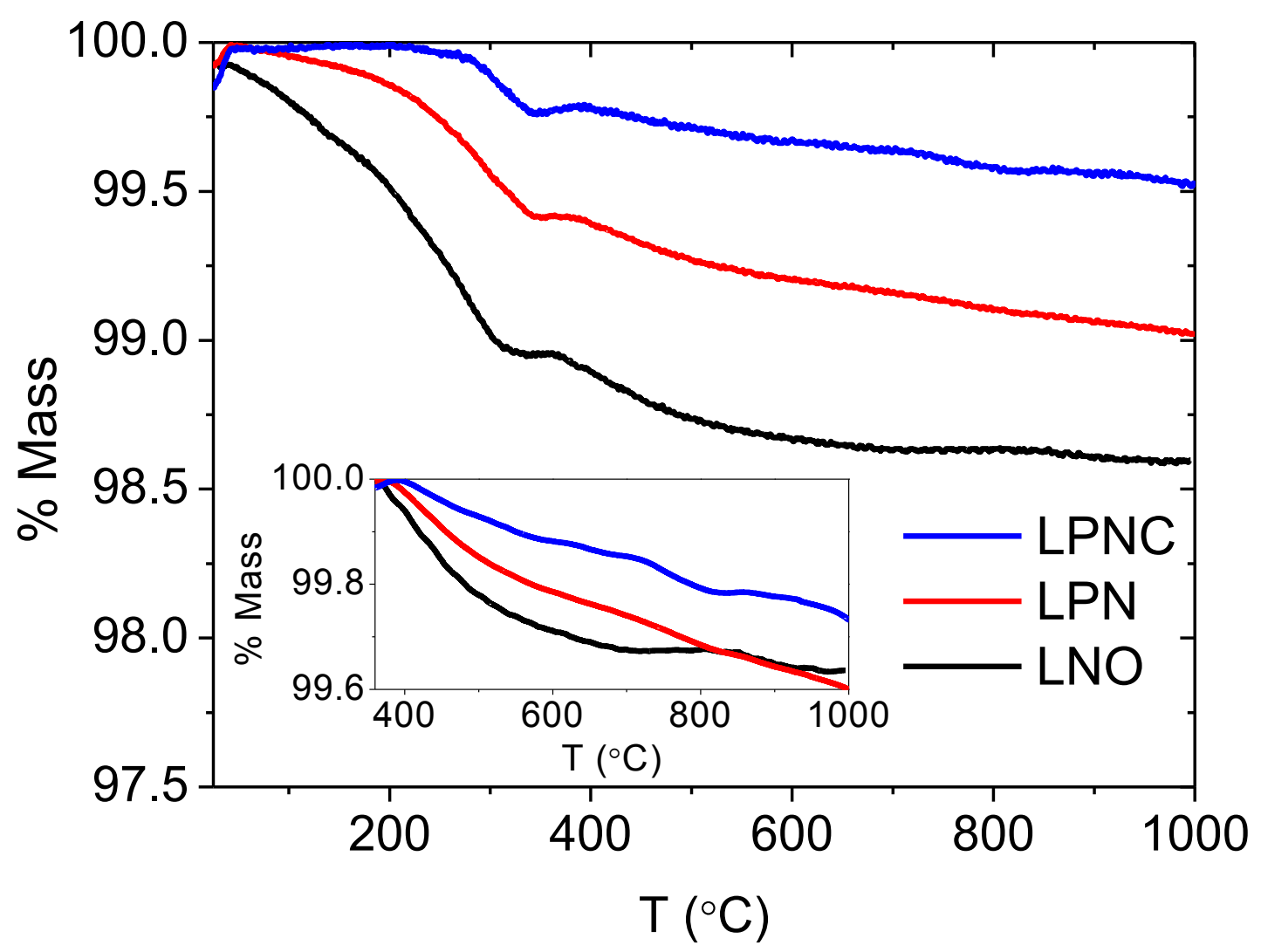

